\title{
The Perceptions of Women's Roles and Progress: A Study of Malay Women
}

\author{
Kalthom Abdullah • Noraini M. Noor · Saodah Wok
}

Accepted: 1 February 2008

(C) Springer Science+Business Media B.V. 2008

\begin{abstract}
This study examines the general perceptions of women towards their roles, their interpretation of progress, as well as the facilitating factors and barriers to their progress. Questionnaires were distributed to 1,000 Malay women in Malaysia from rural and urban areas, from various age and income groups. Interviews were also carried out on the selected sample. Using both quantitative and qualitative methods of analyses, the results showed that women were perceived to play a strong, influential, and supportive role in their families. The results also showed how women perceive progress. These findings are discussed in relation to culture, socialization, values and norms of the Malay society.
\end{abstract}

Keywords Perceptions $\cdot$ Roles $\cdot$ Culture $\cdot$ Women $\cdot$ Progress

\section{Introduction}

Women have made significant progress in education as seen in the increased literacy rates and enrolment in schools and higher educational institutions. Since independence in 1957 there is a steady increase in their participation rates at primary, secondary and tertiary levels of education.

\footnotetext{
K. Abdullah ( $\square)$

Department of Business Administration, Kulliyyah of Economics and Management Sciences, International Islamic University Malaysia, Kuala Lumpur 53100, Malaysia e-mail: kalthom@iiu.edu.my

\section{N. M. Noor}

Department of Psychology, Kulliyyah of Islamic Revealed Knowledge and Human Sciences, International Islamic University Malaysia, Kuala Lumpur 53100, Malaysia

e-mail: noraini@iiu.edu.my

S. Wok

Department of Communication, Kulliyyah of Islamic Revealed Knowledge and Human Sciences, International Islamic University Malaysia, Kuala Lumpur 53100, Malaysia

e-mail: wsaodah@iiu.edu.my
} 
Figures 1-3 show the enrolment of females at the three educational levels. These figures indicate that while in the years following independence males outnumbered females, as of mid-1990s there were more females than males at secondary and tertiary levels.

This increase in the number of female students in higher education can be attributed to a number of reasons, but one important explanation is the step taken at the government level.

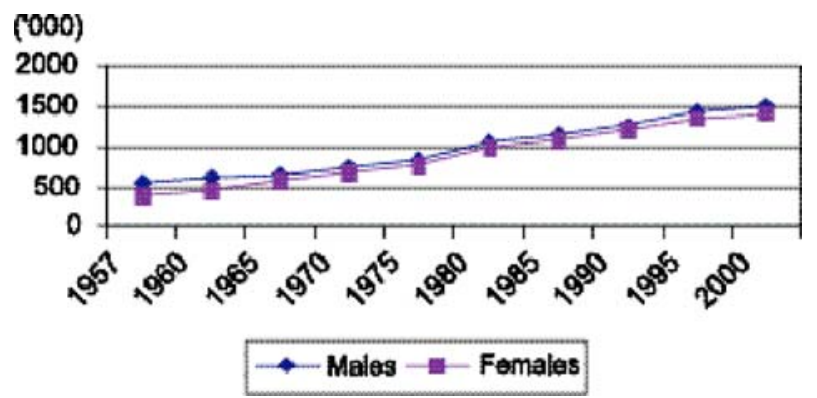

Fig. 1 Primary school enrolment by sex, Malaysia (1957-2000)

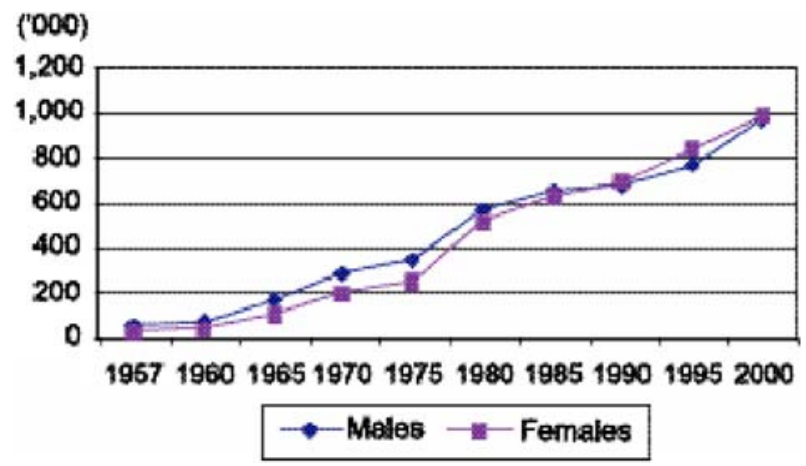

Fig. 2 Secondary school enrolment by sex, Malaysia (1957-2000)

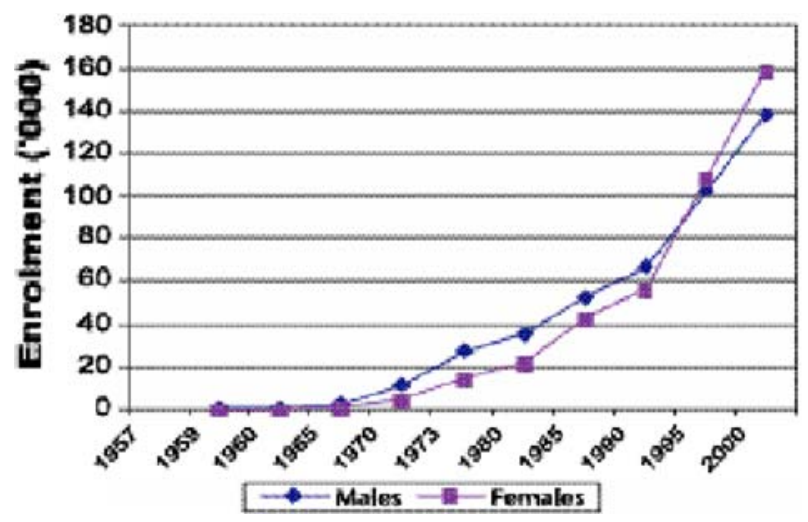

Fig. 3 Enrolment in tertiary institutions by sex, Malaysia (1957-2000) 
In the Sixth Malaysia Plan (1991-1995; the Malaysia Plans are five-year development plans that started in 1970) the government specifically emphasized and focused on issues and strategies for the advancement of women; detailing programs and projects for women's development; recognizing them as an important economic resource and identifying constraints that were inhibiting their full involvement (the previous plans only paid lip service to issues relating to women). In the succeeding development plans (Seventh, Eighth and currently Ninth), efforts to enhance the role, position and status of women increased, particularly the provision of more education and training opportunities to meet the demands of the knowledge-based economy and to improve their upward mobility in the labor market.

Table 1 shows the breakdown of employment by occupation and gender. As can be seen, the percentage of women employed in high paying jobs as senior officials, managers and professionals as well as technicians and associate professionals have increased from 2000 to 2005. In addition, a significant increase can also be seen in the services and sales category. The increase of women in higher paying jobs is mainly due to their educational attainment.

While the female labor force participation rate has increased from $30.8 \%$ at independence in 1957 to $47.8 \%$ in 1991, it has since remained between $45 \%$ and $48 \%$ (see Fig. 4), which reflects a relatively slow growth. Thus, though there are currently more women than men at tertiary level, this is not reflected in the labor force participation rate. It is due to this recognition that the government is aggressively assisting women to work by requesting employers to implement more family-friendly policies such as providing for childcare facilities and more flexible working hours.

This study chooses to focus on Malay women because Malays form the biggest ethnic group in Malaysia (54.2\%) compared to other ethnic groups (Chinese, 25.3\%; Indians, 7.5\%; and others, $1.3 \%$; Ninth Malaysia Plan 2006-2010). Specifically, the study examines women's perception towards their roles, their interpretations of progress, as well as factors that facilitate and hinder their progress. Policy makers can use the findings from this study to assist women to be more empowered and to remain in employment despite family demands. The findings can also create awareness in families and communities to assist women to achieve their goals in life.

Table 1 Employment by occupation and gender, 2000 and 2005

\begin{tabular}{lrrrr}
\hline Occupational category & 2000 & & 2005 \\
\cline { 2 - 5 } & Male & Female & Male & Female \\
\hline Senior officials and managers & 8.0 & 4.8 & 9.4 & 5.4 \\
Professionals & 5.1 & 7.2 & 5.5 & 7.5 \\
Technicians and associate professionals & 10.9 & 14.1 & 12.6 & 14.0 \\
Clerical workers & 5.2 & 18.3 & 4.6 & 17.2 \\
Services and sales workers & 12.9 & 13.3 & 12.3 & 17.7 \\
Skilled agricultural and fishery workers & 17.5 & 10.0 & 14.7 & 9.9 \\
Craft and related trade workers & 11.5 & 4.4 & 15.2 & 5.0 \\
Plant and machine operators and assemblers & 16.2 & 15.8 & 15.9 & 11.5 \\
Elementary occupations & 12.7 & 12.1 & 9.8 & 11.8 \\
Total & 100.0 & 100.0 & 100.0 & 100.0 \\
\hline
\end{tabular}

Source: Economic Planning Unit 


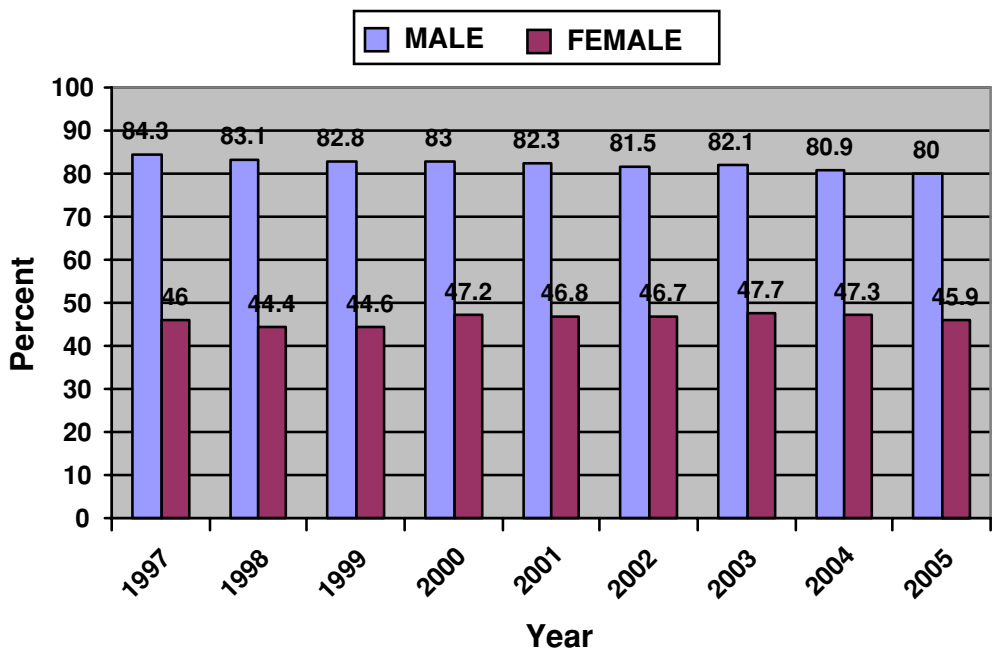

Fig. 4 Labor force participation rate by sex, 1997-2005

\subsection{Perception of Women's Roles}

Several studies suggest that the role of women is prescribed by the society they are socialized in and their religion. In many Asian countries, women are strongly committed to family responsibilities prescribed by their gender role. Women's main role is taking care of children and housework, while men are considered as breadwinners and heads of households. Hofstede and Bond (1988) observed that all Asian cultures are 'collective and familial' and women are expected to assume the responsibility for the home and children. Faced with dual responsibilities of family and office work, employed women are prone to stress and role conflict (Noor 2003).

The burden of work and family is closely related to the trend of an increasing number of single women managers. For example, a study by Ng and Chakrabarty (2005) showed that the rate of women managers who had never married was double the rate of never married male counterparts in Hong Kong. There was also a smaller proportion of women managers in Asia compared to men and this was due to women's lack of self-motivation and the fear that their working hours and frequent travel will affect their family life (Yukongdi and Benson 2005). On the other hand, for those women managers in Asia who want to succeed, they have to face the challenges of the traditional religious views toward women managers. It was further pointed out that women managers resort to personal coping strategies, that is, relying on the support from their extended family and domestic help, when faced with work-family stress. The authors suggested more state childcare, friendly human resource management policies, and a redefinition of the work and family identities to encourage more women participation at the managerial level.

Women managers are less likely to be accepted in the male-dominated culture within work organizations (Westwood and Leung 1999; Ng and Chakrabarty 2005). Job segmentation is also practiced whereby women are placed in supporting departments whereas men are usually placed at the centre of organizational decision-making departments $(\mathrm{Ng}$ and Chakrabarty 2005). Even though East German women may have the opportunity to 
advance their career, they still have to make a choice between career and motherhood (Loderstedt 2005). In the academic field, Curtis (2006) observed that women faculty members have to balance their family obligations with career options unlike men.

In terms of 'role overload', employed women in India faced this situation as they are expected to fulfill their traditional role of the homemaker besides pursuing a career (Aziz 2004). On the other hand, employed Omani women have the support of the family in childcare, conducive working hours and working days. However, they still have to confront the challenges of cultural taboos, negative attitudes, lack of confidence and trust in women managers (Al_Lamki 1999). O'Neil and Bilimoria (2005) found that as women reached mid-career they need to accommodate for family and non-work related activities, and this affects their career patterns.

Malaysian women are also not spared the role conflict that women in other countries faced. In a study on Malaysian women, it was found that, given a choice between work and family, $89.9 \%$ of the women studied chose the family (Noor 2001). At home they spend an average of $3.18 \mathrm{~h}$ in household chores and $4.67 \mathrm{~h}$ in child-care per day, which is much more than the time spent by their husbands. Furthermore, the rise in dual-earner families has resulted in women having to cope with the demands of family obligations and workplace (Noor 2001). Even with job demands these women are still fully committed to their family and when faced with role difficulties, it is their belief in God that helps them deal with these stressful demands.

Despite the increased number of women in the workforce, the general perceptions towards women and their roles have not changed much over the years. As shown by these studies, in many Asian countries women are still perceived as subordinate to men, and employment is an extra, an added-on role, not their primary role. On the basis of these findings, the present study aims to extend and contribute to this literature by considering Malay women's perceptions of their roles and how these perceptions affect their progress. This is much needed in the Malaysian context because of the many changes that are taking place in the country that have directly or indirectly touch on the roles of women (such as the opportunities open to them in education and employment). The study is further warranted due to the dearth of literature in this field.

\section{Methodology}

\subsection{Sample}

The sample comprised of 1,000 Malay women ranging in age from 15 to 67 years with a mean of 33.2 years (standard deviation $=12.1$ years). These women were from rural and urban areas, various occupational groups, levels of education, and income. Table 2 gives the sample characteristics.

For data analysis purposes the sample was split into four age cohorts, representing the teenage years (15-19 years), young adults (20-30 years), middle-aged adults (3145 years), and older adults (46 years and above). Two-thirds of the respondents $(68 \%)$ were in the 20-45 years age bracket corresponding to young and middle-aged women. Ninety-two percent had at least a secondary education, with $49 \%$ having a Diploma and higher. In terms of income, three-quarters were earning less than RM 2,000.00 per month. While $55 \%$ of women were married, $40 \%$ were single and the rest were either divorced or widowed. With respect to place of residents, $58 \%$ were from urban areas and $42 \%$ were from rural areas. 
Table 2 Characteristics of respondents

\begin{tabular}{lc}
\hline Characteristics & Percentage $(N=1,000)$ \\
\hline Age (years) & \\
$15-19$ & 13 \\
$20-30$ & 34 \\
$31-45$ & 34 \\
46 and above & 19 \\
Highest level of education & \\
Not schooling & 1 \\
Primary school (std 1-6) & 7 \\
Secondary school (form 1-6) & 43 \\
Certificate/Diploma & 18 \\
Degree/Master/PhD & 31 \\
Personal income (RM) per month & \\
No income & 26 \\
RM 1000 and less & 27 \\
RM 1001-RM 2000 & 22 \\
RM 2001-RM 3000 & 12 \\
RM 3001-RM 4000 & 6 \\
RM 4001-RM 5000 & 3 \\
More than RM 5000 & 4 \\
Marital status & 58 \\
Single & \\
Married & 42 \\
Divorced/Widow & \\
Place of residence & 55 \\
Urban & \\
Rural & \\
Employment status & \\
Employed & \\
Unemployed & \\
\hline & \\
\hline
\end{tabular}

2.2 Measures and Analyses

A number of multi-item measures were developed to assess the general perception towards Malay women and their roles, women's interpretation of progress, and factors that facilitate and hinder their progress. The measures developed were based on several sources; results of focus group discussion, accepted norms in society, as well as the general literature on women.

1. General perception towards Malay women-respondents were asked to indicate whether they agree or disagree to a list of 12 statements using the Likert-scale format of ' $1=$ strongly disagree' to ' $5=$ strongly agree'. These data on perception of Malay women were analyzed by place of residence (urban vs. rural), employment status (employed vs. unemployed) and age groups (15-19, 20-30, 31-45, 46 years and above) using the independent samples $t$-test and one-way ANOVA.

2. Perception of progress - eight items were identified and respondents were asked to mark the items that were important to them according to the Likert-scale format of 
' $1=$ not important' to ' $5=$ very important'. Similarly, these data on perception of progress were analyzed by place of residence (urban vs. rural), employment status (employed vs. unemployed) and age groups (15-19, 20-30, 31-45, 46 years and above) using the independent samples $t$-test and one-way ANOVA.

3. Factors that facilitate women's progress - six items were listed and respondents were asked to mark the items most relevant to them. These data were again analyzed by place of residence (urban vs. rural), employment status (employed vs. unemployed) and age groups (15-19, 20-30, 31-45, 46 years and above) using descriptive analyses of frequency distributions and percentages.

4. Factors that hinder women's progress-11 items were listed and respondents were asked to rank the items according to ' $1=$ the biggest barrier', ' $2=$ the second barrier', and so on. Similarly, the data were analyzed by place of residence (urban vs. rural), employment status (employed vs. unemployed) and age groups (15-19, 20-30, 31-45, 46 years and above) using descriptive analyses of frequency distributions and percentages.

\section{Results}

\subsection{General Perception Towards Malay Women}

Respondents were asked whether they agreed or disagreed to a list of statements on the general perception towards women. As indicated by the means in Table 3, women were generally perceived as strong, influential, supportive and responsible. The results also showed that respondents perceived women's primary role was to the family, either supporting the husband or nurturing the children, implying that family has priority over work. In addition, women were expected to maintain their femininity, be subservient to the husband and willing to make sacrifices when necessary.

The results of the $t$-tests for the responses on the statements on the perception of women by place of residence showed significant differences $(p<0.05)$ between the urban and rural women on statements two through seven, where rural women tended to endorse these statements more than urban women.

No significant difference in the perception of employed and unemployed women with regards to these statements was found.

The results of the one-way ANOVA for the statements on the perception of women by age-group showed significant differences of opinion between the women of various agegroups on statements $1,5,8,10$, and 12 .

- Statement 1: endorsed more by women above 30 years old.

- Statements 5 \& 8: endorsed more by women above 46 years old.

- Statement 10: endorsed more by women above 20 years old.

- Statement 12: endorsed more by women between 20 and 30 years old.

(Table 4).

\subsection{Perception of Progress}

These women were also asked on how they perceive progress and the results showed that they see progress mainly in terms of their success in playing the role of a homemaker. 
Table 3 Perception towards Malay women by place of residence

\begin{tabular}{|c|c|c|c|c|c|c|c|}
\hline Statements & Residence & $N$ & $M$ & SD & $t$ & df & $p$ \\
\hline \multirow[t]{2}{*}{1} & Urban & 580 & 2.75 & 1.39 & \multirow[t]{2}{*}{.69} & \multirow[t]{2}{*}{998} & \multirow[t]{2}{*}{ NS } \\
\hline & Rural & 420 & 2.69 & 1.37 & & & \\
\hline \multirow[t]{2}{*}{2} & Urban & 580 & 1.87 & 1.01 & \multirow[t]{2}{*}{-1.98} & \multirow[t]{2}{*}{998} & \multirow[t]{2}{*}{.048} \\
\hline & Rural & 420 & 2.00 & 1.07 & & & \\
\hline \multirow[t]{2}{*}{3} & Urban & 580 & 1.82 & .966 & \multirow[t]{2}{*}{-2.41} & \multirow[t]{2}{*}{998} & \multirow[t]{2}{*}{.016} \\
\hline & Rural & 420 & 1.97 & .992 & & & \\
\hline \multirow[t]{2}{*}{4} & Urban & 580 & 1.77 & .952 & \multirow[t]{2}{*}{-2.66} & \multirow[t]{2}{*}{998} & \multirow[t]{2}{*}{.008} \\
\hline & Rural & 420 & 1.94 & 1.02 & & & \\
\hline \multirow[t]{2}{*}{5} & Urban & 580 & 3.68 & 1.01 & \multirow[t]{2}{*}{-2.939} & \multirow[t]{2}{*}{998} & \multirow[t]{2}{*}{.003} \\
\hline & Rural & 420 & 3.87 & 991 & & & \\
\hline \multirow[t]{2}{*}{6} & Urban & 580 & 2.06 & 1.01 & \multirow[t]{2}{*}{-2.06} & \multirow[t]{2}{*}{998} & \multirow[t]{2}{*}{.039} \\
\hline & Rural & 420 & 2.19 & 1.03 & & & \\
\hline \multirow[t]{2}{*}{7} & Urban & 580 & 3.59 & 1.00 & \multirow[t]{2}{*}{-2.37} & \multirow[t]{2}{*}{998} & \multirow[t]{2}{*}{.018} \\
\hline & Rural & 420 & 3.73 & .954 & & & \\
\hline \multirow[t]{2}{*}{8} & Urban & 580 & 3.57 & .891 & \multirow[t]{2}{*}{-.178} & \multirow[t]{2}{*}{998} & \multirow[t]{2}{*}{ NS } \\
\hline & Rural & 420 & 3.58 & .895 & & & \\
\hline \multirow[t]{2}{*}{9} & Urban & 580 & 3.22 & 1.12 & .60 & 998 & NS \\
\hline & Rural & 420 & 3.18 & 1.02 & & & \\
\hline 10 & Urban & 580 & 4.02 & .921 & .64 & 998 & NS \\
\hline & Rural & 420 & 3.98 & .910 & & & \\
\hline 11 & Urban & 580 & 3.87 & 1.99 & -.72 & 998 & NS \\
\hline & Rural & 420 & 3.95 & .961 & & & \\
\hline 12 & Urban & 580 & 4.38 & .838 & -1.91 & 998 & NS \\
\hline & Rural & 420 & 4.48 & .767 & & & \\
\hline
\end{tabular}

Note:

- Statement 1: No matter how high a woman's education is, her place is in the kitchen.

- Statement 2: A woman cannot excel in her career and housework at the same time.

- Statement 3: It is not proper for a woman to show off her ability at the workplace.

- Statement 4: A woman should not compete with men.

- Statement 5: A woman should maintain her gentle and shy behavior.

- Statement 6: A woman should follow orders without arguing.

- Statement 7: A woman should be subservient to her husband.

- Statement 8: A woman should be willing to make sacrifices.

- Statement 9: A woman should not ask for material things.

- Statement 10: A man depends on the support of a woman to be successful.

- Statement 11: A mother is more responsible in molding the personality of the children than the men.

- Statement 12: The hand that rocks the cradle rules the world.

- $\mathrm{NS}=$ Not significant

Besides religious knowledge, the three most important indicators of progress are having successful children, academic achievement, and income.

The results of the independent $t$-test between urban and rural women's perception of progress showed a significant difference between the two groups only for the item on 
Table 4 Perception towards Malay women by age-groups ${ }^{\mathrm{a}}$

\begin{tabular}{|c|c|c|c|c|c|c|}
\hline Statements & Mean & SD & $F$ & $\mathrm{df}$ & $p$ & Comparison \\
\hline \multirow[t]{4}{*}{1} & $\mathrm{G} 1=2.60$ & 1.36 & \multirow[t]{4}{*}{6.12} & \multirow[t]{4}{*}{3,996} & \multirow[t]{4}{*}{.0001} & \multirow{4}{*}{$\begin{array}{l}\text { Significant between } \mathrm{G} 2 \text { and } \mathrm{G} 3 \\
\quad p=.001 \\
\text { Significant between } \mathrm{G} 2 \text { and } \mathrm{G} 4 \\
\quad p=.046\end{array}$} \\
\hline & $\mathrm{G} 2=2.50$ & 1.30 & & & & \\
\hline & $\mathrm{G} 3=2.92$ & 1.40 & & & & \\
\hline & $\mathrm{G} 4=2.85$ & 1.47 & & & & \\
\hline \multirow[t]{4}{*}{2} & $\mathrm{G} 1=1.93$ & 1.07 & \multirow[t]{4}{*}{1.16} & \multirow[t]{4}{*}{3,996} & \multirow[t]{4}{*}{.324} & \multirow[t]{4}{*}{ Not significant } \\
\hline & $\mathrm{G} 2=1.91$ & 1.04 & & & & \\
\hline & $\mathrm{G} 3=1.99$ & 1.10 & & & & \\
\hline & $\mathrm{G} 4=1.82$ & 0.88 & & & & \\
\hline \multirow[t]{4}{*}{3} & $\mathrm{G} 1=1.84$ & 1.03 & \multirow[t]{4}{*}{2.32} & \multirow[t]{4}{*}{3,996} & \multirow[t]{4}{*}{.073} & \multirow[t]{4}{*}{ Not significant } \\
\hline & $\mathrm{G} 2=1.78$ & 0.92 & & & & \\
\hline & $\mathrm{G} 3=1.93$ & 1.01 & & & & \\
\hline & $\mathrm{G} 4=1.99$ & 0.97 & & & & \\
\hline \multirow[t]{4}{*}{4} & $\mathrm{G} 1=1.81$ & 1.00 & \multirow[t]{4}{*}{1.68} & \multirow[t]{4}{*}{3,996} & \multirow[t]{4}{*}{.171} & \multirow[t]{4}{*}{ Not significant } \\
\hline & $\mathrm{G} 2=1.75$ & 0.93 & & & & \\
\hline & $\mathrm{G} 3=1.91$ & 1.04 & & & & \\
\hline & $\mathrm{G} 4=1.88$ & 0.96 & & & & \\
\hline \multirow[t]{4}{*}{5} & $\mathrm{G} 1=3.60$ & 1.10 & \multirow[t]{4}{*}{3.99} & \multirow[t]{4}{*}{3,996} & \multirow[t]{4}{*}{.008} & Significant between G1 and G4, \\
\hline & $\mathrm{G} 2=3.75$ & 1.00 & & & & $p=.016$ \\
\hline & $\mathrm{G} 3=3.71$ & 0.99 & & & & \\
\hline & $\mathrm{G} 4=3.96$ & 0.93 & & & & \\
\hline 6 & $\mathrm{G} 1=2.13$ & 1.00 & 1.12 & 3,996 & .341 & Not significant \\
\hline & $\mathrm{G} 2=2.05$ & 1.05 & & & & \\
\hline & $\mathrm{G} 3=2.11$ & 0.99 & & & & \\
\hline & $\mathrm{G} 4=2.21$ & 1.03 & & & & \\
\hline 7 & $\mathrm{G} 1=3.61$ & 1.00 & 2.49 & 3,996 & .059 & Not significant \\
\hline & $\mathrm{G} 2=3.65$ & 0.98 & & & & \\
\hline & $\mathrm{G} 3=3.57$ & 0.99 & & & & \\
\hline & $\mathrm{G} 4=3.81$ & 0.97 & & & & \\
\hline 8 & $\mathrm{G} 1=3.45$ & 0.94 & 8.65 & 3,996 & .0001 & Significant between G1 and G4, \\
\hline & $\mathrm{G} 2=3.54$ & 0.85 & & & & $p=.001$ \\
\hline & $\mathrm{G} 3=3.49$ & 0.95 & & & & Significant between $\mathrm{G} 2$ and $\mathrm{G} 4$, \\
\hline & $\mathrm{G} 4=3.86$ & 0.76 & & & & $p=.001$ \\
\hline & & & & & & $\begin{array}{l}\text { Significant between G3 and G4, } \\
\quad p=.0001\end{array}$ \\
\hline 9 & $\mathrm{G} 1=3.04$ & 1.05 & 2.07 & 3,996 & .102 & Not significant \\
\hline & $\mathrm{G} 2=3.21$ & 1.04 & & & & \\
\hline & $\mathrm{G} 3=3.18$ & 1.12 & & & & \\
\hline & $\mathrm{G} 4=3.34$ & 1.09 & & & & \\
\hline 10 & $\mathrm{G} 1=3.63$ & 1.02 & 9.26 & 3,996 & .0001 & Significant between G1 and G2, \\
\hline & $\mathrm{G} 2=4.10$ & 0.90 & & & & $p=.000$ \\
\hline & $\mathrm{G} 3=4.01$ & 0.91 & & & & Significant between G1 and G3, \\
\hline & $\mathrm{G} 4=4.08$ & 0.82 & & & & $p=.001$ \\
\hline & & & & & & $\begin{array}{l}\text { Significant between } \mathrm{G} 1 \text { and } \mathrm{G} 4 \text {, } \\
\quad p=.000\end{array}$ \\
\hline
\end{tabular}


Table 4 continued

\begin{tabular}{lllllll}
\hline Statements & Mean & SD & $F$ & df & $p$ & Comparison \\
\hline 11 & G1 $=3.84$ & 1.07 & 1.31 & 3,996 & .269 & Not significant \\
G2 $=3.81$ & 1.05 & & & & \\
G3 $=3.92$ & 2.43 & & & & \\
12 & G4 $=4.09$ & 0.97 & & & & Significant between G1 and G2, \\
& G1 $=4.24$ & 0.95 & 2.76 & 3,996 & .041 & \\
& G2 $=4.47$ & 0.80 & & & & \\
G3 $=4.44$ & 0.77 & & & & \\
G4 $=4.45$ & 0.77 & & & & \\
\hline
\end{tabular}

Note:

- Statement 1: No matter how high a woman's education is, her place is in the kitchen.

- Statement 2: A woman cannot excel in her career and housework at the same time.

- Statement 3: It is not proper for a woman to show off her ability at the workplace.

- Statement 4: A woman should not compete with men.

- Statement 5: A woman should maintain her gentle and shy behaviour.

- Statement 6: A woman should follow orders without arguing.

- Statement 7: A woman should be subservient to her husband.

- Statement 8: A woman should be willing to make sacrifices.

- Statement 9: A woman should not ask for material things.

- Statement 10: A man depends on the support of a woman to be successful.

- Statement 11: A mother is more responsible in molding the personality of the children than the men.

- Statement 12: The hand that rocks the cradle rules the world.

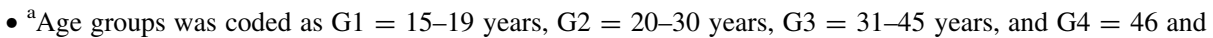
above

successful children, where rural women considered this indicator as more important than urban women (mean $=4.73$ and 4.65 respectively, $p<0.05$ ) (Table 5).

No significant difference was found between the employed and unemployed on all the indicators of progress.

The one-way ANOVA for the perception of progress by age-groups indicated that those in the 20-45 years age groups (young and middle-aged women) rated the indicators pertaining to income, wealth/material, and status and position as more important than the teenagers and the oldest age group. Results further showed that for marriage, successful children, and religious knowledge, those in the 46 years and above age group perceived these as being more important indicators than those who were younger. On the other hand, academic achievement was considered as more important by those in the 15-19 years age group (Table 6)

\subsection{Factors that Facilitate Progress}

Family not only served as indicator of progress, it also facilitated women's progress. Apart from their own efforts, loans and scholarships, these women also received support from their family in the form of sponsorship to improve themselves. 
Table 5 Perception of progress by place of residence

\begin{tabular}{llllllll}
\hline Statements & Residence & $N$ & $M$ & SD & $t$ & df & $p$ \\
\hline 1. Income & Urban & 580 & 4.59 & .64 & -.94 & 998 & NS \\
& Rural & 420 & 4.62 & .61 & & & \\
2. Wealth/Material things & Urban & 580 & 3.95 & .84 & .26 & 998 & NS \\
& Rural & 420 & 3.93 & .87 & & & \\
3. Status/Position & Urban & 580 & 3.47 & .91 & 1.87 & 998 & NS \\
& Rural & 420 & 3.36 & .97 & & & \\
4. Marriage & Urban & 580 & 4.01 & .85 & -1.54 & 998 & NS \\
5. Successful Children & Rural & 420 & 4.09 & .90 & & & \\
& Urban & 580 & 4.65 & .63 & -2.16 & 998 & .031 \\
6. Academic Achievement & Rural & 420 & 4.73 & .56 & & & \\
& Urban & 580 & 4.67 & .59 & -.56 & 998 & NS \\
7. Religious Knowledge & Rural & 420 & 4.69 & .62 & & & \\
& Urban & 580 & 4.89 & .40 & -.94 & 998 & NS \\
& Rural & 420 & 4.92 & .30 & & & \\
\hline
\end{tabular}

Urban women relied mainly on the availability of scholarship, financial support from parents, their own efforts, education loan and financial support from family members respectively. Rural women, on the other hand, resorted to support from family members, education loan, own efforts, financial support from parents and scholarships respectively (Table 7).

With respect to employment status, while employed women resorted to applying for scholarship besides seeking financial help from family members and parents respectively, those unemployed applied for education loan and own efforts before seeking financial help from parents and family members (Table 8).

Those in the 15-19 years age-group depended mainly on their parents, while those in the 20-30 years age bracket relied on education loans, parents, scholarship, and family members. Older women (those above 31 years upwards) tended to be more self-reliant than the younger ones (Table 9).

\subsection{Factors that Hinder Progress}

When asked on the obstacles that prevented respondents from progressing further in their lives, rural women mentioned in-laws, husbands and education as barriers while urban women reported that employers, opportunity/chances to improve and general knowledge as factors impeding their progress (Table 10).

Employed women reported that husbands and in-laws hindered them from progressing further in their lives, while those unemployed cited money, lack of opportunity/chances to improve and education as their main obstacles (Table 11).

A closer examination by age groups indicated that teenagers (15-19 years age group) cited general knowledge, parents, level of education, and money as their obstacles. The 20-30 years age group, on the other hand, mentioned parents, chances to improve, money and general knowledge, while those belonging to the 31-45 years age group mentioned children, husbands, in-laws, parents, and employers. The oldest age group mentioned 
Table 6 Perception of progress by age-groups ${ }^{\mathrm{a}}$

\begin{tabular}{|c|c|c|c|c|c|c|}
\hline Statements & Mean & SD & $F$ & df & $p$ & Comparison \\
\hline 1. Income & $\begin{aligned} \mathrm{G} 1 & =4.46 \\
\mathrm{G} 2 & =4.66 \\
\mathrm{G} 3 & =4.62 \\
\mathrm{G} 4 & =4.58\end{aligned}$ & $\begin{array}{l}0.80 \\
0.55 \\
0.62 \\
0.61\end{array}$ & 3.26 & 3,996 & .021 & $\begin{array}{l}\text { Significant between } \mathrm{G} 1 \text { and } \mathrm{G} 2 \text {, } \\
\quad p=.027\end{array}$ \\
\hline 2. Wealth/Material things & $\begin{aligned} \mathrm{G} 1 & =3.93 \\
\mathrm{G} 2 & =4.00 \\
\mathrm{G} 3 & =3.90 \\
\mathrm{G} 4 & =3.92\end{aligned}$ & $\begin{array}{l}0.85 \\
0.77 \\
0.89 \\
0.94\end{array}$ & .90 & 3,996 & .443 & Not significant \\
\hline 3. Status/Position & $\begin{aligned} \mathrm{G} 1 & =3.59 \\
\mathrm{G} 2 & =3.44 \\
\mathrm{G} 3 & =3.43 \\
\mathrm{G} 4 & =3.27\end{aligned}$ & $\begin{array}{l}0.98 \\
0.88 \\
0.94 \\
0.99\end{array}$ & 3.16 & 3,996 & .024 & $\begin{array}{l}\text { Significant between } \mathrm{G} 1 \text { and } \mathrm{G} 4 \text {, } \\
\quad p=.028\end{array}$ \\
\hline 4. Marriage & $\begin{aligned} \mathrm{G} 1 & =3.60 \\
\mathrm{G} 2 & =4.06 \\
\mathrm{G} 3 & =4.12 \\
\mathrm{G} 4 & =4.18\end{aligned}$ & $\begin{array}{l}1.04 \\
0.82 \\
0.82 \\
0.83\end{array}$ & 15.12 & 3,996 & .000 & $\begin{array}{l}\text { Significant between G1 and G2, } \\
\quad p=.0001 \\
\text { Significant between G1 and G3, } \\
\quad p=.0001 \\
\text { Significant between G1 and G4, } \\
\quad p=.0001\end{array}$ \\
\hline 5. Successful children & $\begin{aligned} \mathrm{G} 1 & =4.41 \\
\mathrm{G} 2 & =4.65 \\
\mathrm{G} 3 & =4.78 \\
\mathrm{G} 4 & =4.80\end{aligned}$ & $\begin{array}{l}0.83 \\
0.58 \\
0.52 \\
0.48\end{array}$ & 15.68 & 3,996 & .000 & $\begin{array}{l}\text { Significant between } \mathrm{G} 1 \text { and } \mathrm{G} 2, \\
\quad p=.001 \\
\text { Significant between } \mathrm{G} 1 \text { and G3, } \\
\quad p=.0001 \\
\text { Significant between } \mathrm{G} 1 \text { and G4, } \\
\quad p=.0001\end{array}$ \\
\hline 6.. Academic achievement & $\begin{aligned} \mathrm{G} 1 & =4.79 \\
\mathrm{G} 2 & =4.63 \\
\mathrm{G} 3 & =4.70 \\
\mathrm{G} 4 & =4.65\end{aligned}$ & $\begin{array}{l}0.47 \\
0.61 \\
0.59 \\
0.69\end{array}$ & 2.80 & 3,996 & .039 & Not significant \\
\hline 7. Religious knowledge & $\begin{aligned} \mathrm{G} 1 & =4.88 \\
\mathrm{G} 2 & =4.89 \\
\mathrm{G} 3 & =4.90 \\
\mathrm{G} 4 & =4.94\end{aligned}$ & $\begin{array}{l}0.37 \\
0.36 \\
0.42 \\
0.23\end{array}$ & .98 & 3,996 & .403 & Not significant \\
\hline
\end{tabular}

Note: ${ }^{a}$ Age groups was coded as G1 $=15-19$ years, G2 $=20-30$ years, G3 = 31-45 years, and G4 = 46 and above

Table 7 Factors that facilitate progress by place of residence

\begin{tabular}{lccr}
\hline Items & Urban $N(\%)$ & Rural $N(\%)$ & Total \\
\hline Education loan & $101(56.4 \%)$ & $78(43.6 \%)$ & 179 \\
Scholarship & $85(69.1 \%)$ & $38(30.9 \%)$ & 123 \\
Financial support from parents & $236(62.6 \%)$ & $141(37.4 \%)$ & 377 \\
Financial support from family members & $90(54.9 \%)$ & $74(45.1 \%)$ & 164 \\
Own efforts & $353(56.9 \%)$ & $267(43.1 \%)$ & 620 \\
\hline
\end{tabular}


Table 8 Factors that facilitate progress by employment status

\begin{tabular}{lccc}
\hline Items & Employed $N(\%)$ & Unemployed $N(\%)$ & Total \\
\hline Education loan & $103(60.9 \%)$ & $66(39.1 \%)$ & 169 \\
Scholarship & $80(71.4 \%)$ & $32(28.6 \%)$ & 112 \\
Financial support from parents & $225(65.8 \%)$ & $117(34.2 \%)$ & 342 \\
Financial support from family members & $101(66.9 \%)$ & $50(33.1 \% 0$ & 151 \\
Own efforts & $359(64.1 \%)$ & $201(35.9 \%)$ & 560 \\
\hline
\end{tabular}

Table 9 Factors that facilitate progress by age-groups

\begin{tabular}{|c|c|c|c|c|c|}
\hline Items & $\begin{array}{l}15-19 \text { years } \\
N(\%)\end{array}$ & $\begin{array}{l}20-30 \text { years } \\
N(\%)\end{array}$ & $\begin{array}{l}31-45 \text { years } \\
N(\%)\end{array}$ & $\begin{array}{l}46 \text { years \& above } \\
N(\%)\end{array}$ & Total \\
\hline Education loan & $6(3.4 \%)$ & $120(67.0 \%)$ & $47(26.3 \%)$ & $6(3.4 \%)$ & 179 \\
\hline Scholarship & $20(16.3 \%)$ & $45(36.6 \%)$ & $40(32.5 \%)$ & $18(14.6 \%)$ & 123 \\
\hline Financial support from parents & $91(24.3 \%)$ & $159(42.5 \%)$ & $96(25.7 \%)$ & $28(7.5 \%)$ & 374 \\
\hline $\begin{array}{l}\text { Financial support from } \\
\text { family members }\end{array}$ & $21(12.9 \%)$ & $59(36.2 \%)$ & $49(30.1 \%)$ & $34(20.9 \%)$ & 163 \\
\hline Own efforts & $52(8.4 \%)$ & $190(30.7 \%)$ & $236(38.1 \%)$ & $141(22.8 \%)$ & 619 \\
\hline
\end{tabular}

Table 10 Obstacles to progress by place of residence

\begin{tabular}{lrrr}
\hline Items & \multicolumn{1}{l}{ Urban } & Rural & Total \\
& \multicolumn{1}{c}{$N(\%)$} & $N(\%)$ & \\
\hline Family—children & $106(53.8 \%)$ & $91(46.2 \%)$ & 197 \\
Family—husband & $92(51.7 \%)$ & $86(48.3 \%)$ & 178 \\
Family—parents & $73(54.5 \%)$ & $61(45.5 \%)$ & 134 \\
Family—other family members & $65(54.2 \%)$ & $55(45.8 \%)$ & 120 \\
Workplace—employer & $98(61.3 \%)$ & $62(38.8 \%)$ & 160 \\
Family—in-laws & $57(50.9 \%)$ & $55(49.1 \%)$ & 112 \\
Self-achievement-level of education & $268(53.3 \%)$ & $235(46.7 \%)$ & 503 \\
Self-achievement-general knowledge & $248(56.9 \%)$ & $188(43.1 \%)$ & 436 \\
Material—money & $348(56.4 \%)$ & $269(43.6 \%)$ & 617 \\
Opportunity—chances to improve & $424(58.3 \%)$ & $303(41.7 \%$ & 727 \\
\hline
\end{tabular}

in-laws, followed by education, children, and husbands. Across all age groups, more women in the 20-30 years age group attribute their obstacles to progress to factors pertaining to lack of chances and general knowledge (Table 12).

\section{Discussion}

The present study found that after nearly 50 years of independence, Malay women still closely adhere to their traditional cultural values where they are expected to be strong as a mother, while remaining effeminate and subservient as a wife. The results also showed that 
Table 11 Obstacles to progress by employment status

\begin{tabular}{llll}
\hline Items & Employed & Unemployed & Total \\
& $N(\%)$ & $N(\%)$ & 180 \\
\hline Family_children & $128(71.1 \%)$ & $52(28.9 \%)$ & 162 \\
Family_husband & $121(74.7 \%)$ & $41(25.3 \%)$ & 121 \\
Family-parents & $87(71.9 \%)$ & $34(28.1 \%)$ & 109 \\
Family-other family members & $79(72.5 \%)$ & $30(27.5 \%)$ & 139 \\
Workplace-employer & $99(71.2 \%)$ & $40(28.8 \%)$ & 102 \\
Family-in-laws & $76(74.5 \%)$ & $26(25.5 \%)$ & 463 \\
Self-achievement-level of education & $299(64.6 \%)$ & $164(35.4 \%)$ & 396 \\
Self-achievement-general knowledge & $259(65.4 \%)$ & $137(34.6 \%)$ & 555 \\
Material-money & $352(63.4 \%)$ & $203(36.6 \%)$ & 658 \\
Opportunity-chances to improve & $424(64.4 \%)$ & $234(35.6 \%)$ & \\
\hline
\end{tabular}

Table 12 Obstacles to progress by age-groups

\begin{tabular}{lccccc}
\hline Items & $\begin{array}{l}15-19 \text { years } \\
N(\%)\end{array}$ & $\begin{array}{l}20-30 \text { years } \\
N(\%)\end{array}$ & $\begin{array}{l}31-45 \text { years } \\
N(\%)\end{array}$ & $\begin{array}{l}\text { 46 years \& above } \\
N(\%)\end{array}$ & Total \\
\hline Family_children & $5(2.5 \%)$ & $45(22.8 \%)$ & $107(54.3 \%)$ & $40(20.3 \%)$ & 197 \\
Family-husband & $8(4.5 \%)$ & $45(25.3 \%)$ & $89(50.0 \%)$ & $36(20.2 \%)$ & 178 \\
Family-parents & $22(16.4 \%)$ & $54(40.3 \%)$ & $44(32.8 \%)$ & $14(10.4 \%)$ & 134 \\
Family-other family & $8(6.7 \%)$ & $40(33.3 \%)$ & $49(40.8 \%)$ & $23(19.2 \%)$ & 120 \\
$\quad$ members & $13(8.1 \%)$ & $57(35.6 \%)$ & $66(41.3 \%)$ & $24(15.0 \%)$ & 160 \\
Workplace-employer & $7(6.3 \%)$ & $32(28.8 \%)$ & $49(44.1 \%)$ & $23(20.7 \%)$ & 111 \\
$\begin{array}{l}\text { Family-in-laws } \\
\text { Self-achievement- }\end{array} \quad$ level of education & $73(14.5 \%)$ & $162(32.2 \%)$ & $168(33.4 \%)$ & $100(19.9 \%)$ & 503 \\
Self-achievement- & $69(15.8 \%)$ & $162(37.2 \%)$ & $136(31.2 \%)$ & $69(15.8 \%)$ & 436 \\
$\quad$ general knowledge & $87(14.1 \%)$ & $232(37.7 \%)$ & $202(32.8 \%)$ & $95(15.4 \%)$ & 616 \\
$\begin{array}{l}\text { Material-money } \\
\text { Opportunity-chances to improve }\end{array}$ & $97(13.4 \%)$ & $281(38.8 \%)$ & $224(30.9 \%)$ & $122(16.9 \%)$ & 724 \\
\hline
\end{tabular}

rural women endorsed these latter values more than urban women. To a large extent, this is to be expected considering that rural women have lower educational levels and are less likely to be employed.

Even with employment women are still perceived to be primarily responsible for the home and children. The results of the present study showed that this perception is held by both employed and unemployed women. This may be one reason why many are quite satisfied to remain where they are in their present work situation although they could achieve and do more; they just do not have the time or energy to do both equally well and this coupled with traditional expectations (such as however high a woman's education is, her place is still in the kitchen) stop them from progressing in their career.

While age has some influence on the perception of Malay women, some items remained salient for all age groups. Older women (31 years and above) were more likely to see women's place still to be in the kitchen despite having high education. Compared to the 
younger groups, the oldest group perceived that women have to make sacrifices, and they also should be shy and gentle. The younger women, on the other hand, recognized that as women, they too are powerful and has a role to play ("The hands that rock the cradle rules the world." and "A man depends on the support of a woman to be successful"). In contrast, respondents, regardless of their age groups, seemed to agree that women cannot excel at work and home simultaneously, should not compete with men nor show off their ability, to be obedient and not demanding. Further, they are more responsible to the children than the men. Thus, while women have been given the opportunities to education and employment, many aspect of their roles still remain unchanged.

The three main indicators of progress identified by the women, besides religious knowledge, were having successful children, academic achievement and income. To succeed, academic achievement is required and money/income can make this possible. Rural women reported having successful children as a more important indicator than urban women because they usually place more emphasis on family relationship. As expected, women between the ages of 20-45 rated the indicators pertaining to income, wealth and status/position as more important that the other two age groups because this phase of life entails more demands (raising a family and cost of children's education, buying a house and other essentials, etc.). In addition, the most important indicator of progress for the youngest age group was academic achievement, while religious and spiritual issues become more dominant for those aged 46 years and above.

Family members, especially parents, husbands and children provided the much needed support (both financial and emotional) to help women in their progress. While rural women depended more on the family, urban women have more options (such as scholarships and loans) to help them. As expected, the youngest group (15-19 years) depended on their parents, while the older groups are more self-reliant.

In contrast, the factors mentioned as hindering them from progress were lack of opportunities, money and qualification (low education). In addition, family members can also impede women's progress, as mentioned by these women. Rural women reported inlaws, husbands and education as factors impeding their progress. Those who were employed also mentioned husbands and in-laws, while the unemployed mentioned lack of opportunity and knowledge. The fact that husbands is mentioned as an obstacle is in line with research showing that for women, support from husbands is important, more so when they are employed. Studies have shown that employed wives are distressed when husbands do not participate at home (Mederer 1993; Perry-Jenkins and Folk 1994). What is crucial here is spouse support, in terms of their attitudes towards their wives' employment and with respect to their participation at home. In a study of dual-earner couples, Greenberger and O'Neil (1993) found that while men's well-being was chiefly associated with social support from their wives, women's well-being was linked to social support from husbands, neighbors, supervisors and co-workers. This is so because women currently live their lives at home and at work and they need the support from all relevant parties.

In-laws were also cited as being an obstacle to women's progress. In the Malay context, when a woman gets married, she is "married" not only to the man, but also to the in-laws (Noor 2001). In the rural setting, the woman usually lives with her in-laws, while many young urban couples also live with their in-laws before they can afford a place of their own. Thus, frictions are bound to occur, especially if the woman is not seen as following traditions.

A major challenge facing women in Malaysia is the lack of fit between the supports offered by social institutions (workplace, community) and demands of the family. In Malaysia, although $47 \%$ of women are in the working age population of 15-64 years, they only accounted for a third of the labor force (Ninth Malaysia Plan 2006-2010). And, 
despite calls by the government, this number has not increased much in the last decade. One of the reasons for this is due to the fact that workplaces and government are not seen to be doing enough to help employed women. For example, to encourage women with families to work, the government introduced flexible working hours under the Employment Act of 1955 (amended in 1998) with benefits to be paid to part-time workers proportionate to that of full-time employees. In reality, however, many workplaces do not recognize parttime work. Those employed on a part-time basis are usually at a disadvantage (benefits are usually not recognized, no opportunity for advancement or promotion, tasks given are usually routine and unchallenging) and as a result, they would rather not be employed. Furthermore, many workplaces are not seen to be "family-friendly" (workplaces that provide for flexible work arrangements, provision of child/elder care referrals and centers).

Findings from previous studies have suggested that women cannot evade from the responsibilities assigned to them by traditions and religions even though they are holding managerial positions. In the same vein, Malaysian women are also facing the same role conflict and related stress. Previous studies of women in other countries have shown that they are able to deal with the role conflict through family support and hiring domestic help, support from the organizations ( $\mathrm{Ng}$ and Chakrabarty 2005) as well as support from the government in terms of conducive working hours and days (Aziz 2004). If these supportive elements are properly put in place, Malay women can be motivated to pursue equal career opportunity as men without feeling guilty of forsaking their responsibilities.

\section{Implications of the Findings}

The purpose of the present study was to examine the general perceptions of women towards their roles, their interpretation of progress, as well as factors that facilitate and hinder their progress. Women's role is oriented more towards family matters rather than self-fulfillment implying that when faced with having to make a choice between career and family, family is always given priority. In a way, the present Malay women are caught in a dilemma between the modern challenges of life and traditions. While many are now employed, they are still expected to be responsible for the family and to maintain the traditional perception of a woman. To do so, women need a lot of support; from the family, workplace as well as the society.

O'Neil and Bilimorie (2005) suggested that in order to retain talented professional women, organizations need to understand and provide support to women's career and relationship priorities. Thus, certain skills such as time-management skills, assertiveness skills, and technological skills among others could be provided to these women. They should be groomed to accept more challenging tasks and their talents should be acknowledged.

At home, a more cooperative environment could be fostered if good parenting skills were taught to potential newly-weds and young parents to avert stress and role-conflict on the women.

The government could also help by providing monitored and safe facilities for childcare such as nurseries and day-care centers so that employed women can focus on their careers knowing that their children are in safe hands. With many unemployed graduates in this country, this pool of educated human resource could be channeled to mind these facilities with proper training. The government could also organize short courses for women who want to learn computer skills, business skills and even image building skills so that they could be self-reliant and confident. For the rural women they could be taught sewing skills 
and other related craftwork that would benefit them. Finally, society's perceptions towards women need to change to take into consideration the present demands that are placed on them. While this may take time, women on the their part, must start changing the stereotypical ways that they are perceived, at least by making some changes within their individual families.

Acknowledgement The authors acknowledge the support of UNILEVER Malaysia Sdn. Bhd. for sponsoring this study.

\section{References}

Al_Lamki, S. M. (1999). Paradigm shift: A perspective on Omani women in management in the Sultanate of Oman. Advancing Women in Leadership AWL Journal, 2, Spring Issue.

Aziz, M. (2004). Role stress among women in the Indian Information Technology sector. Women in Management Review, 19, 356-363.

Curtis, J. W. (2006). Balancing work and family for faculty: Why it's important. Retrieved on May 11, 2006 from the World Wide Web http://www.aaup.org/publications/Academy2004/04nd/04ndcurt.htm.

Greenberger, E., \& O'Neil, R. (1993). Spouse, parent, worker: Role commitments and role related experiences in the construction of adults' well-being. Developmental Psychology, 29, 181-197.

Hofstede, G., \& Bond, M. H. (1988). The Confucius connection: From cultural roots to economic growth. Organizational Dynamics, 16, 5-21.

Loderstedt, K. (2005). East German women in management. Women in Management Review, 2, 329-44.

Mederer, H. J. (1993). Division of labor in two-earner homes: Task accomplishment versus household management as critical variables in perceptions about family work. Journal of Marriage and the Family, 55, 133-145.

Ninth Malaysia Plan (2006-2010). Kuala Lumpur: Percetakan Nasional Berhad.

Ng, C. W., \& Chakrabarty, A. S. (2005). Women managers in Hong Kong: Personal and practical agendas. Asia Pacific Business Review, 11, 163-178.

Noor, N. M. (2001). Work, family and well-being: Challenges of contemporary Malaysian women. Kuala Lumpur: IIUM Press.

Noor, N. M. (2003). Work- and family-role experiences, work-family conflict and women's well-being: Some observations. Community, Work and Family, 6, 297-319.

O'Neil, D. A., \& Bilimoria, D. (2005). Women's career development phases-idealism, endurance, and reinvention. Career Development International, 10, 168-189.

Perry-Jenkins, M., \& Folk, K. (1994). Class, couples and conflict: Effects of the division of labor on assessments of marriage in dual-earner families. Journal of Marriage and the Family, 56, 165-180.

Westwood, R., \& Leung, A. S. M. (1999). Women in management in Hong Kong and Beijing. In P. Fosh, A. W. Chan, W. W. S. Chow, E. Shape, \& R. Westwood (Eds). Hong Kong management and labour: Change and continuity (pp. 199-219). London: Routledge.

Yukongdi, V., \& Benson, J. (2005). Women in Asia management: Cracking the glass ceiling? Asia Pacific Business Review, 11, 139-148. 